\title{
Leaving Islam
}

\author{
Christine Schirrmacher
}

Looked at from a global perspective, possibly more people than ever are changing or leaving their religion. At the same time, while it is legally impossible to leave Islam in all Middle Eastern countries, it is considered to be a punishable crime under Sharia law, and the death penalty can be applied in a handful of countries like Saudi-Arabia or Iran. Interestingly enough, the Koran does not seem to have a clear verdict on apostasy. Muslim theologians hold different views as to whether Islam favors complete religious freedom or whether the culprit is unpunishable as long as he does not rock the boat of the community. Many Muslim theologians still hold to the death penalty.

2

Key Terms

The term for "unbelief" or "non-belief" (Arabic: kufr) is used 482 times in the Koran. In at least 19 verses it is used in the sense of turning away or falling away from Islam (Hallaq 2001: 119-122). There is no mention in the Koran of the Arabic term for "apostasy," which is ridda and irtidād in Arabic.

However, one finds neither in the Koran nor in tradition an unambiguous definition for when apostasy from Islam (Arabic: al-ruğ '́c'an dìn al-islām or qaț al-islām) is unquestionably present, how it can be determined, and whether saying the creed is sufficient in order to avert the charge of apostasy (Griffel 1998: 356). Indeed, there is widespread consensus that apostasy undoubtedly exists where the truth of the Koran is denied, where blasphemy is committed against God, Islam, or Muhammad, and where breaking away from the Islamic faith in word or deed occurs. The lasting, willful non-observance of the five pillars of Islam, in particular the duty to pray, clearly count as apostasy for most theologians. Additional distinguishing features are a change of religion, confessing atheism, nullifying the Sharia as well as judging what is allowed to be forbidden and judging what is forbidden to be allowed. Fighting against Muslims and Islam (Arabic: muḥāraba) also counts as unbelief or apostasy; 
likewise, numerous theologians judge apostasy to be a form of battle against Islam.

\section{$3 \quad$ Historical Developments}

Overall, our knowledge about how the topic of apostasy has been dealt with in Islam in the close to 14 centuries of Islamic history is limited: Apart from few sources relating to the time of the Middle Ages and the Ottoman Empire, we primarily have sources at our disposal which are from the early days of Islam as well as from the 19th and 2oth centuries.

Already around the time of Muhammad's death in 632 A.D., there arose a number of Arab voices against Islamic domination which saw themselves only personally bound to Muhammad. Fighting erupted under the first Caliph Abū Bakr, which has gone down in history as the "Apostasy Wars" (Arabic: hurüb ar-ridda). The reason for the outbreak of uprisings has been disputed within research: For instance, the continued existence of pre-Islamic social structures is supposed, such that a protective relationship was linked exclusively to an influential leader (Hasemann 2002: 37). Or was the uprising determined by the desire to avoid the collection of taxes and to cast off the rulers from Medina? In such case one would only be able to speak conditionally about the term apostasy (Hallaq 2001: 120-121).

There are only a few known individual cases of the use of the death penalty for apostates dating from the 8th century. The reason for this could be that it was first of all in the course of Abbasid rule from the end of the 8th century onwards that prosecution and the imposition of the death penalty set in. In the Umayyad and early Abbasid periods, the defensive measures against apostates appear to have mostly remained limited to intellectual debates (Cook 2006: $256 ; 276-277$ ).

From this time, there are only a few individual cases of the prosecution of apostates which have been handed down: According thereto, Hišām Ibn 'Abd al-Malik was executed for spreading Mu'tazilite convictions in 742 or 743 . In 784, the Iraqi writer Bašār Ibn Burd was killed on account of apostasy and in 922 al-Husayn ibn Manșūr al-Hallăğ on account of blasphemy. A number of additional individual cases have to do with prior Christians, who owing to their conversion and their subsequent return to the Christian faith were reportedly executed: Tradition includes the name Kyros and his execution by burning in the year 769, the execution of "Holy Elias" in 795, the killing of "Holy Bacchus" in 806; two additional cases are known from the 1oth and 14th centuries (Khoury 1994: 101-192) as well as a number from Islamic Spain, for instance, in the 11th century (Wasserstein 1993). 
From the 9th century onwards, a time in which the execution of apostates becomes historically tangible, complaints become vociferous that the charge of apostasy set in as a weapon against undesired opponents. For example, Abū Ḥāmid Muḥammad ibn Muhammad al-Ġazālī (d. 1111) raged against the excessive practice of condemning others as "unbelievers" (Arabic: takfir) among theologians (Lewis 2002: 144). There are reports from this time about the reconversion of prior non-Muslim detainees after their release. The question of whether it was a matter of heresy was decided by means of questioning those involved, namely whether they spoke "words of unbelief" (Arabic: kalimāt alkufr). For these "words of unbelief," there existed prior to the 12th century no exact definition. Since one considered the inner convictions of a person to not be justiciable, legal experts at that time appear to have generally been more cautious to judge belief or unbelief (Olsson 2008: 95). For that reason, many scholars appear to have concentrated more on the political aspect of the question, namely whether the involved individual caused revolt and rebellion. It was believed that such occurrences were able to be more clearly judged.

Tilman Nagel names the Maliki scholar al-Qāḍī Ijāọ (d. 1149) as the first individual who called for the death penalty for "disseminating improprieties about Muhammad or questioning his authority in all questions of faith and profane life" and, with that, shook the foundation of Muslim community. Later, the Hanbalite theologian Ibn Taimiya (d. 1328) and the Shafiite scholar Taqī ad-Dīn as-Subkī (d.1355) followed this reasoning (Nagel 2001: 295). From the 12th century, especially during the Mamlük Period (Levanoni 2016), and then in particular from the 14th century onwards, there are a number of cases of executions of apostates which have come down in tradition (Cook 2006: $257 ; 275)$.

The Ottoman Empire offers a more easily researchable arena as to how apostasy was dealt with. A number of reports are available from the 19th century on the execution of apostates. This was a time when there was intensive struggle between the representatives of Western powers and the Sublime Porte (High Porte) about the justification of these executions. Indeed, the Hatt-i Sharif decree by Sultan Abdülmecid I in 1839 provided all Ottoman subjects with protection of life, of honor, and of possessions independent of their religion. Strictly speaking, however, converts were not included. For example, the British envoy to the court of Sultan Abdülmecid I (1839-1861), Stratford Canning, intensively campaigned with the support of diplomatic representatives from Austria, Russia, Prussia, and France at the Sublime Porte for a prohibition on the execution of apostates. What followed was a long period marked by a diplomatic tug-ofwar: While the British envoy made determined attempts to move the Sublime Porte to change its laws with respect to the criminal prosecution of apostates, the Sublime Porte, for its part, sought to be as decided in not giving in to the 
urging and straitjacketing by the envoys of Europe. In the end, Sultan Abdülmecid granted a decree to Stratford Canning in which the Sultan, over against the High Porte, stated that he would support the High Porte's preventing the prosecution and execution of apostates (Deringil 2000: 556; 559).

Cases of the execution of apostates reported out of Egypt are also known from the 19th century, such as, for instance, the killing of female apostates from the years 1825 and 1835 (Peters and De Vries 1976: 13). After that, there appear to have been very few cases of execution for apostasy from the next 150 years which are known about (exceptions are, for example, the stoning of Ṣahịzzādah 'Abd al-Lațîf [1903] and Maulawī Ni'mat Allāh after converting to the Ahmadiya movement in Afghanistan [1924]) (Ahmad 1989: 16).

It was not until the 2oth century that the topic of apostasy developed a new dynamic: Theologians increasingly drafted tracts and papers in which the use of the death penalty for apostasy was called for while at the same time most Muslim majority states in the 2oth century, in the course of nation building, formulated constitutions affirming religious freedom. Only in the fewest of these constitutions is apostasy from Islam taken to be a criminal offense; it can, for example, be punished in Saudi Arabia with the death penalty (although the country has no constitution), in Yemen, Mauretania, and in Iran. However, apostasy from Islam in the public sphere is now predominantly interpreted as a political offense, and there are more than a few position statements condemning it as an action endangering the state which has to be immediately halted.

Since Sharia law in the 2oth century has been limited to family law for the majority of the states in the MENA region, a legal charge on account of apostasy is only possible in those few states which have codified Sharia law into penal law. Resourceful protagonists, however, have occasionally taken the way of efforts of a hisba legal action (as, for instance, in the case of the Koran scholar Nașr Hāmid Abū Zaid in Egypt in 1993) under the pretext of wanting to protect the Islamic community from the political offense of revolt. It was not until 1996 that there was a law prohibiting individuals from bringing a hisba legal action before a court due to alleged apostasy by a third party. The sole exception has to do with the plaintiff's being able to credibly demonstrate a personal and direct interest in the legal action (Bälz 1997: 141).

Traditionally, apostasy counts as a capital offense (hudüd offense) according to Sharia law. Nowadays, this classification is viewed critically by an increasing number of theologians. Up to the present day, the legal imposition of the death penalty for apostasy is possible where Sharia law has been codified in penal law. However, in Muslim majority countries or states characterised by Islam, public apostasy from Islam has social as well as legal consequences: 
Apostasy is frequently viewed socially as a disgrace, treason, and a scandal. Being ostracised and cast out of the family are possible results, as are the loss of one's employment and in dramatic cases persecution and the use of force up to the point of attempting to seek to kill the apostate, incarcerate the individual, and to torture the individual (Marshall and Shea 2011: 61). Legal consequences can be disinheritance (since according to Sharia law non-Muslims are not allowed to inherit from Muslims), forced divorce (since according to Sharia law a Muslim female may not be married to a non-Muslim man), or having one's own children and the custody of those children taken away (since according to Sharia law Muslim children may not be raised by non-Muslims).

\section{$4 \quad$ Major Controversies and Significant Incidents}

There are essentially three main positions within Islamic theology today when it comes to the question of religious freedom. There is a liberal or progressive position, which advocates complete religious freedom, including the right of being allowed to leave Islam. There is a restrictive position, which basically rejects religious freedom for Muslims and which seeks to penalise criticism of Islam or its progressive interpretation with the death penalty. Finally, there is a centrist or moderate position, which a majority of theologians might be considered to support today.

Supporters of the restrictive position cite texts from the early days of Islam when justifying the death penalty, for instance Muhammad's call to kill apostates as well as the tradition of the companions of the Prophet and caliphs who report cases of beheading and crucifixion. Since over the course of the history of theology the call for the death penalty for apostasy formulated in the early days of Islam has not been declared to be invalid, and since the principle justification of punishment of renegades had essentially never been placed into question by influential committees of scholars using a historical hermeneutical approach, recourse to texts from the early days of Islam have remained an acknowledged instrument for abstracting guidelines for dealing with apostates in the 2oth century.

Nowadays, representatives of the liberal position likewise refer to texts from the early days in order to justify complete religious freedom. They point to texts within tradition which report on Muhammad's rejection of punishment of apostates as well as Koran verses, such as Sura 2:256, which deny "compulsion in religion." In the course of their defusing the guidelines for the execution of apostates, they differentiate between theological and political concerns with respect to the topic of apostasy. Indeed, according to the opinion of the 
majority of representatives of this position, it is also neither desirable nor is it meaningless with respect to the assessment of the individual in the Last Judgment. Nevertheless, it is not to be subject to punishment. Punishment, they hold, would contradict what is for them the intrinsic principle of free will. Since it is held that the Islamic community is not threatened by what is in total a low number of apostates, the prosecution of individual apostates in the early days of Islam cannot be taken as a guideline for dealing with those who change religions in the present day.

In contrast, the centrist or moderate position advocates freedom of belief for Muslims, which exclusively means internal thoughts. At the same time, freedom to openly confess adherence to another religion or to no religion is rejected. On the one hand, there is a warning against premature allegations and calls for execution of those whose apostasy is not unambiguously provable. On the other hand, however, it advocates execution as an obligatory action according to Sharia law in the case of proven apostates who make their turning away from Islam public. In the same way as representatives of the restrictive position, they condemn turning away from Islam as a political offense that brings unrest into the state and society and causes revolt.

The following three contemporary examples illustrate that it is often difficult, if not dangerous, to leave Islam in Muslim majority societies around the world. The first example of Yousef Nadarkhani demonstrates that in Iran the charge of apostasy, punishment, and incarceration also applies while there is no written law in the constitution which forbids converting to another religion. The second case of Farag Foda from Egypt illustrates that the said apostasy has been interpreted as a public crime by some members of society, holding that a court case is not a necessary requirement for punishing an "unbeliever," whereas the third case of Mohammad Younus Sheikh from Pakistan shows that his continuing confession that he has remained a Muslim believer has not been seen as relevant with respect to his being charged with apostasy.

The pastor Yousef Nadarkhani, a convert to the Christian faith and the pastor of an underground Protestant Iranian church, was initially imprisoned in 2006 and then again in 2009 and 2012 on account of apostasy. In a judgment by the First Chamber of the Revolutionary Court on September 22, 2010, Nadarkhani was sentenced to death by hanging for "the dissemination of non-Islamic teaching" and "apostasy from the Islamic faith." On June 28, 2011, the sentencing was confirmed by the Third Chamber of the Supreme Court in Qom. Gholamali Rezvani, the Vice Governor of the Gilan province, labeled pastor Nadarkhani a "zionist" who was "guilty of corruption and had committed high treason." Iranian media labeled him a "rapist," "burglar," and an "extortionist." At the beginning of July 2011, Nadarkhani's prior lawyer Mohammad Ali Dadkhah had 
been sentenced to receive lashes, 9 years of imprisonment, and a 10-year occupational ban as a lecturer and lawyer as well as being sentenced to pay a fine. ${ }^{1}$

In September 2012, Yousef Nadarkhani was surprisingly set free, supposedly not least because of numerous international press reports and political advocacy in that same year. However, a short time later, he was again arrested, allegedly on account of some sort of irregularity. After being released again, Yousef Nadarkhani continued to work as a pastor but was permanently harassed by the Iranian authorities and eventually incarcerated again. In July 2017, he was sentenced to ten years of imprisonment and subsequently two years of exile 1,200 miles away from his hometown and family.

Nadarkhani was arguably the first convert in whose case the Iranian justice system openly named "apostasy from Islam" as the reason for its death sentence in 2010. Earlier converts were officially charged with other offenses, such as "spying" or "drug dealing." In the case of Mehdi Dibaj in 1994, he was detained for years, but was reportedly never given a reason for his arrest. He was then abducted in the middle of the street and later found dead (Sanasarian 2000: 124f.). Since 1996, due to a change in the penal code, insulting Muhammad is indeed threatened with the death penalty but up to now the Iranian penal code does not contain any paragraph explicitly calling for the death penalty. On the contrary, Iran, by signing the International Covenant on Civil and Political Rights, has taken on the obligation of guaranteeing freedom of thought, freedom of conscience, and freedom of religion.

Another significant incident was the author and intellectual Farag Foda. He was murdered by two members of the al-ğamāa $a$ al-islāmìya group on June 8, 1992 in Cairo. This occurred after he had already been openly accused of apostasy and unbelief for some time by various individuals. He had also been challenged by renowned representatives of Islamism in rebuttal of his viewpoints, which had a secular orientation (Soage 2007: 26). Among these were, for instance, his assertion that the application of Sharia law and the imitation of the habits and customs of the early days of Islam were an ineffective way of improving the numerous social problems in Egypt (Fūda 2003: 31). The freedom of opinion, democracy, an improved legal position for the Coptic minority as well as the separation of religion and politics were some additional items he called for.

Foda's murder was preceded by a fatwa by the chairman of the al-Azhar fatwā committee on February 1, 1990, which generally rejected the application

1 International Society for Human Rights (ISHR): https://www.igfm.de/youcef-nadarkhani/; https://www.igfm.de/news/article/irans-bekanntester-pastor-zu-zehn-jahren-haftverurteilt/ (November 17, 2017). 
of hadd punishment for apostasy (Najjar 1996: 6). However, two years later, on June 3, 1992, a second fatwa was issued which contained a personal vilification of Foda, threats, and his condemnation as a blasphemer and apostate. This had been instigated by a group of Azhar scholars. Foda was murdered five days later in broad daylight. Due to the lack of criminal legislation for the case of apostasy, the responsible members of the al-Azhar faculty would not have been able to have themselves carried out the execution of this individual whom they viewed to be guilty, and they would not have been able to move the state to apply the death penalty on account of apostasy. However, owing to their office and based on appealing to their religious authority, they personally convinced the hired assassins, as one of them confessed in his later hearing, that Foda's murder had been a religious duty (Rubin 2006:1).

In the subsequent trial of Foda's murderer before the Supreme State Security Court in Cairo, Muhammad al-Ġazâlī was asked for a statement. In his statement, al-Ġazâlī called for excluding every apostate from the community, his condemnation to death by the ruler as well as the unconditional enforcement of hadd punishment. He continued that an individual who prematurely kills the apostate arguably commits an act of unauthorised "assumption of authority," but Islam does not stipulate a punishment for that. This assumption of authority only repairs the "shame" that exists in the fact that state power does not enforce the appropriate punishment.

al-Giazâlī used disparaging wording when he spoke about the apostate, saying that Foda was "acting like a germ in society," who "spits out his poison and urges people to leave Islam" (Fähndrich 1994: 56) as Foda did not keep his flagrant unbelief for himself. Rather, he proclaimed it publicly and, with that said, according to al-Gazālī, undermined Islam, which in the final event promotes Zionism and colonialism (O'Sullivan 2003: 107).

The Egyptian scholar Muḥammad Mazrū'a expressed himself more aggressively, indicating that the killing of Foda was necessary for maintaining the Muslim community since the state apparently was not willing to act. For that reason, the defendants were not guilty (Mazrū'a 1994). Indeed, what followed was a court case against Foda's attackers and their subsequent condemnation and execution on account of murder, but there were also public demonstrations which showed unconcealed delight and support for the offenders.

A third case is Dr. Muhammad Younus Shaikh, a physician educated in Pakistan and Great Britain and a professor of anatomy at the Homeopathic Medical College in Islamabad, a human rights activist. As the founder of the movement The Enlightenment, he expressed his rejection of Pakistani support of "freedom fighters" in Kashmir (Hassan 2008: 29) on October 1, 2000 at a conference of the South Asia Union. He declared himself in favor of recognising 
the present line of demarcation between Pakistan and Kashmir as an international border, whereupon a high-ranking member of the Pakistani military who was present is said to have made blatant threats against Shaikh.

Only a few days later, he was suspended from his position at the Homeopathic Medical College, and on that same evening one of his students with a close tie to the Pakistani government filed a complaint on account of blasphemy according to $\S 295-\mathrm{C}$. He supposedly made "blasphemous remarks" about Muhammad (International Humanist and Ethical Union 2004). According to the complaint, he was arrested on October 4, 2000 despite testimony to his innocence. The "Movement for the Finality of the Prophet" group led a mob onto the street, which threatened to set the College and the police station on fire (Marshall; Shea 2011: 98). Younus Shaikh initially remained in solitary confinement until August 2001 (according to official information this was for his own protection). However, after nearly 11 months of imprisonment, the Islamabad Additional District and Sessions Court sentenced Shaikh on August 18, 2001 to the payment of 1 million Rupees and to death. In the course of the appeal proceedings, the High Court in Rawalpindi rejected his request for release against bail on January 1, 2002, supposedly in order to protect him from execution in broad daylight.

In July 2002, after an additional 15 months of solitary confinement, new hearings were conducted in connection with the case. There was no lawyer who dared to come to Shaikh's defense. On October 9, 2003, around three years after the indictment, the court finally judged that the first instance court's determination was incorrect. However, Younus Shaikh was not released. Rather, the case was referred back to the lower court. In November 2003 there were three hearings appointed: On November 21, 2003, after more than three years of imprisonment and the loss of his entire livelihood, the defendant was secretly released on the grounds that his accusers had made false accusations. He immediately received asylum in Switzerland since there was a fatwa calling for his assassination (Schirrmacher 2016: 110-112).

A number of verses in the Koran appear to leave the freedom of choice to individuals in questions of faith, for example when Sura 2:256 formulates it as follows: "Let there be no compulsion in religion." Additional verses call believers to forgive those who solicit leaving the faith (for example, Sura 2:109), even if departing from the faith is unambiguously referred to as "straying" (arab. dalla) (Sura 2:108). These and quite a number of additional verses in the Koran warn 
of the error of heresy but do not name a punishment the heretic has to face in this world. However, the majority of them warn of the punishment of hell in the next world (Sura 4:115), God's anger, and his punishment or "the curse of God, of His angels, and of mankind" (Arabic: la'nat allāh wa-'l-maläika wa-'n$n \bar{a} s$ ) (Sura 3:87): God will not forgive the apostate (Sura 4:137). However, when Sura 2:217, for instance, disapproves of misleading other people to apostasy as more serious than killing a person, even here the consequence mentioned is exclusively a punishment in the next life and not worldly judgment.

Sura 9:74 makes an exception insofar as the threat of a "grievous penalty in this life and in the Hereafter" (Arabic: 'adāäban aliman fi'd-dunyā wa-'-l-ăhira) is found, but admittedly this "penalty" is not concretely defined. Also, Sura 4:8889 speaks of hypocrites (Arabic: al-munäfiqūn), who desire that everyone were as unbelieving as they are. After that, there is the call to "seize" and "slay" those who turn away (Arabic: fa-hudūhum wa-qtulūhum); Sura 9:11-12 also admonishes believers to fight those who have come into the Muslim community and then, however, "violate their oaths" (Arabic: nakațu aimānahum).

On the basis of this ambiguous textual finding, those who advocate religious freedom as well as those who reject it call upon the Koran (and tradition). Advocates of religious freedom argue using Sura 2:256 ("Let there be no compulsion in religion") as well as the Koran's disapproval of turning away from belief and the certainty of God's punishment of the apostate. They also use the Koran's lack of mention of a process for determining apostasy nor mention of a punishment in this world. In addition, they say that according to reports of tradition, Muhammad himself pardoned apostates and did not execute them (Friedmann 2003: 125; 131). To model his example would in their view mean to likewise not condemn apostates nowadays.

Advocates of the death penalty for apostasy argue, in contrast, by using verses such as Sura 4:89 (“... but if they turn renegades, seize them and slay them ...") as well as by using texts found in tradition, which in the case of "apostasy" (Arabic: ridda) depict the execution of apostates in the early Islamic community and expressly call for the enforcement of the death penalty for apostasy. The text, quoted exceedingly conspicuously, is traceable back to Muhammad's dictum: "Whoever changes his religion, kill him" (Buhāāī) (Arabic: man baddala dinnahu fa-'qtulūhu). However, this counts as only one text conveyed by a single conveyor of tradition (hadit al-ahad) and thereby does not belong to those texts with undisputed authority.

Other texts, which have been cited to justify the legitimacy of the death penalty, are, for instance, an account traced back to Ibn 'Abbās as well as to 'Ā'iša, according to which Muhammad allowed the execution of an individual who had separated himself from the community and had turned his back on Islam 
(Buhārī, Muslim). The hadīt text is traceable back to Buhārī, in which the blood of a Muslim is allowed to be shed in only three cases, namely due to apostasy from Islam, adultery, and the killing of an individual which was not blood revenge. The text is often quoted in this connection. A number of the texts name beheading by the sword, crucifixion, and banishment (Nasāīi) as permissible forms of execution and punishment, although the burning of non-believers and heretics (Buhārī) by Muḥammad's cousin and son-in-law, 'Alī, was disapproved of by Anās b. Mālik.

Abdullah Saeed (b. 1960), professor of Arabic and Islamic studies, was born on the Maldives. His school education was completed in Pakistan, and the first portion of his studies, up to the receipt of his B.A. in Arabic and Islamic Studies, was completed in Saudi Arabia. In 2004, with his brother, the former Attorney General of the Maldives, Hassan Saeed, he wrote Freedom of Religion, Apostasy and Islam (Saeed and Saeed 2004), in which he makes an emphatic call to revise the apostasy legislation found in classical Islamic law and in which complete freedom of religion is justified from Islamic source texts. Abdullah Saeed's significance lies in his widespread activity in a number of countries in Asia, to which his numerous invitations, conference addresses as well as his publications on the three continents of Europe, Australia, and Asia bear eloquent witness. Additionally, the fact that he consults the Australian government with respect to questions of integration of the Muslim minority and publishes domestic studies in cooperation with various governmental institutions means that his expositions have international reach.

On the basis of his numerous as well as influential offices held around the globe, the large number of book publications of around 120 titles, his fatāwa , articles, public addresses, sermons, and his broad teaching and consulting activities for various banks and financial institutions, his enduring media presence with his own television program on $\mathrm{Al}$ Jazeera and his extensive use of the internet with a number of his own websites, Yūsuf al-Qaraḍāwī (b. 1926) counts as perhaps the most influential living Sunni theologian of all. He permanently promotes his method of interpretation of "centrism" and "moderation" (wasațīya and itidāl) and thus offers Muslim youth, in the Western diaspora in particular, a paradigm for behavior and identity which marks him off not only as a theologian but also as a socio-political personality who engages himself in a very targeted manner in current debates and markets his positions on what is "forbidden" (harām) and what is "allowed" (haläl) with a 
sense of significant authority and media impact. In his book ğarimat ar-ridda wa-'uqübat al-murtadd fì dau' al-qur'ān wa-'s-sunna (The Crime of Apostasy and the Punishment of Apostates in the Light of Koran and Sunna) (al-Qaraḍāwī 1996), al-Qaradāwī takes a middle path. On the one hand, he does not distance himself from instruction to apply the death penalty to apostates anchored in Islamic law. On the contrary, he emphasises that administering capital punishment, as it is particularly formulated in tradition and as it was applied by Muhammad as well as by the companions of the Prophet, is not a negotiable issue when it comes to the protection of society. On the other hand, however, he links certain conditions to imposing capital punishment for apostasy and emphasises that the execution of an apostate is not possible in every case and not without careful investigation. His moderation in relation to the punishment of apostasy thus lies in his conceding the possibility that in certain cases an apostate is not to be executed if it is a matter of the forum internum, the innermost, non-justiciable area of freedom of thought and of conscience of an individual which is not visible to the outside.

Abū l-Álā Maudūdī (1903-1979) was one of the most influential Islamic intellectuals, ideologues, and theologians up to the present today. His work on the topic of apostasy, murtadd ki sazā islämì qānūn meñ (The Punishment of the apostate according to Islamic Law) (Maudūdì 1942/43), is dedicated to addressing the question of the maintenance and the secure continuation of the Islamic state in which Islam is meant to be the sole identity and foundation of the legal system and legislation. This Islamic state is, from Maudūdī's point of view, threatened from the outside - above all through the invasion of Western powers. However, it is also threatened by the ideologies which materialism, and godlessness propagate. However, the community of the "protected persons" (Arabic: dimmī) does not present a danger if its members remain within their own limited area where they are free to move. But the case of dealing with apostates is essentially different: These individuals have decided to rebel. For that reason, the topic of apostasy for Maudūdī is in the first instance not a religious or a theological question but rather, above all, a politically motivated, deliberate attack on the Islamic state. Given, Maudūdīs thinking, the apostate is dangerous and a pathogenous bacillus that spreads its "poison" thus inducing the destruction of society. Therefore, the apostate is not to be tolerated; within a period of one year, the apostate either has to be forced to migrate or be executed. The apostate, from Maudūdì's point of view, has given up his nationality and can claim no rights - also not the right to life. Maudūdì made no difference between the quiet doubter and the open propagandist with newly won views. He did not differentiate between personal freedom of belief and publicly practicing religious freedom and religious adherence. 


\section{Conclusions}

The large majority of Muslims do not hold the opinion that the Koran explicitly demands the application of the death penalty for apostasy, whereas at the same time the sunna reports traditions of Muhammad where he is said to have condemned apostates to death. Sharia law makes the death penalty obligatory for those who voluntarily and willfully leave their religion, although capital punishment seems to have been applied only in rare cases throughout history. Today, there are three major positions among Muslim theologians: One minority consists of those who are openly advocating complete religious freedom, while another minority consists of those who deem the death penalty necessary under all circumstances. A majority are those who advocate religious freedom of the inner heart but forbid open propagation of changing or leaving Islam. In cases where converts or "liberals" are threatened with violence, the power factor seems to overlap with the theological discussion.

\section{References}

Ahmad, Syed Barakat. 1989. "Conversion from Islam." In Bosworth, C.E. et al. eds, The Islamic World from Classical to Modern Times. Princeton: The Darwin Press, 3-25.

Bälz, Kilian. 1997. "Submitting Faith to Judicial Scrutiny through the Family Trial: The 'Abū Zayd Case." Die Welt des Islams. 37:2, 135-155.

Cook, David. 2006. "Apostasy from Islam: A Historical Perspective." Jerusalem Studies in Arabic and Islam. 31, 248-288.

Deringil, Selim. 2000. 'There is no Compulsion in Religion:' On Conversion and Apostasy in the Late Ottoman Empire: 1839-1856." Comparative Studies of Society and History. 42:3, 547-575.

International Humanist and Ethical Union.2004. "Dr Younus Shaikh Free!" 23.01.2004. At:http://iheu.org/dr-younus-shaikh-free/. Accessed 25/5/2017.

Fähndrich, Hartmut. 1994. "Der Kasus Farag Foda." In Du. Islam - Die Begegnung am Mittelmeer. $640,55^{-56}$.

Fūda, Farağ. 2003. al-haquīqa al-gààiba. al-Iskandarīya: dār wa-mațābi' al-mustaqbal.

Friedmann, Yohanan. 2003. Tolerance and Coercion in Islam. Interfaith Relations in the Muslim Tradition. Cambridge: Cambridge University Press.

Griffel, Frank. 1998. "Die Anwendung des Apostasieurteils bei aš-Šāfīì und al-Ġazālī.” In S. Wild, and H. Schild eds, Akten des 27. Orientalistentages: Norm und Abweichung. Würzburg: Ergon, 353-362.

Hallaq, Wael. 2001 "Apostasy." Encyclopaedia of the Quran, Vol. I. Leiden:E.J. Brill, 119-122. Hasemann, Armin. 2002. "Zur Apostasiediskussion im Modernen Ägypten." Die Welt des Islams. 42:1, 72-121. 
Hassan, Riaz. 2008. Inside Muslim Minds. Carlton: Melbourne University Press.

Khoury, Adel Theodoro. 1994. Christen unterm Halbmond. Religiöse Minderheiten unter der Herrschaft des Islams. Freiburg: Herder.

Larsson, Göran. 2017. "Apostasy and Counter-Narratives - Two Sides of the Same Coin: The Example of the Islamic State." The Review of Faith \& International Affairs. 15:2, $45^{-54}$.

Levanoni, Amalia. 2015. "Takfír in Egypt and Syria during the Mamlūk Period." In C. Adang, H. Ansari, M. Fierro, and S. Schmidtke, eds, Accusations of Unbelief: A Diacronic Perspective on Takfir. Leiden: E.J. Brill, $155^{-188 .}$

Lewis, Bernard. 2002. Die politische Sprache des Islam. Hamburg: Europäische Verlagsanstalt.

Marshall, Paul; Shea, Nina. 2011. Silenced. How Apostasy \& Blasphemy Codes are Choking Freedom Worldwide. Oxford: Oxford University Press.

Mazrū'a, Muḥammad. 1994. ahkām al-ridda wa-'-murtaddīn min hilāl šahādatai alĠazālìwa-Mazrū'a. al-Qāhira.

Nagel, Tilman. 2001. Das islamische Recht. Eine Einführung. Westhofen: WVA Skulima.

Najjar, Fauzi. 1996. "The Debate on Islam and Secularism in Egypt." Arab Studies Quarterly. 18:2, 1-21.

Olsson, Susanne. 2008. “Apostasy in Egypt. Contemporary Cases of Hisbah." The Muslim World. 98:1, 95-115.

O'Sullivan, Declan. 2003. "Egyptian Cases of Blasphemy and Apostasy against Islam: Takfir al-Muslim (Prohibition against Attacking those Accused)." International Journal of Human Rights. 7:2, 97-137.

Peters, Rudolph; De Vries, Gert J.J. 1976. “Apostasy in Islam." Die Welt des Islams. 25: 1-4, $1-25$.

al-Qaraḍāwī, Yūsuf. 1996. ğarìmat ar-ridda wa-'uqūbat al-murtadd fì dau' al-qur'ān wa's-sunna. al-Qāhira: maktabat wahba.

Rubin, Barry. 2006. The Long War for Freedom. The Arab Struggle for Democracy in the Middle East. Hoboken: John Wiley \& Sons.

Saeed, Abdullah; Saeed, Hassan. 2004. Freedom of Religion, Apostasy and Islam. Aldershot: Ashgate.

Sanasarian, Eliz. 2000. Religious Minorities in Iran. Cambridge: Cambridge University Press.

Schirrmacher, Christine. 2016. "Let there be no Compulsion in Religion" (Sura 2:256). Apostasy from Islam as Judged by Contemporary Islamic Theologians. Discourses on Apostasy, Religious Freedom, and Human Rights. Eugene/Oregon: Wipf \& Stock (in German: Christine Schirrmacher. 2015. "Es ist kein Zwang in der Religion" (Sure 2,256). Der Abfall vom Islam im Urteil zeitgenössischer islamischer Theologen. Diskurse zu Apostasie, Religionsfreiheit und Menschenrechten. Würzburg: Ergon). 
Soage, Ana Belén. 2007. "Faraj Fowda, or the Cost of Freedom of Expression." The Middle East Review of International Affairs. 11:2, 26-33.

Wasserstein, David. 1993. "A Fatwā on Conversion in Islamic Spain." Studies in MuslimJewish Relations. 1, 177-188. 